\title{
Compaction Characteristics of the Lateritic Soil-Mango Leaf Ash Admixed with Cement
}

\author{
Ishola K., Olawuyi O.A., and Kareem M.A.
}

\begin{abstract}
This study investigated the compaction effect of unmodified and modified lateritic soil using cement-mango leaf waste ash (C- MLWA). The lateritic soil used was classified as A-7-6 (9) and CL using AASHTO soil classification and USCS respectively. The soil was treated with a blended cement of 1\%,2 \% and $6 \%$ mango leaf waste ash by dry weight of the soil sample. Effect of cement- mango leaf ash on the modified soil was studied with respect to compaction characteristics, plasticity characteristics, particle size distribution, California bearing ratio, and unconfined compressive strength. Compactive efforts used were British Standard Light (BSL) and West African Standard and the results were examined utilizing analysis of variance (ANOVA) Method. The research shows an increase in MDD with the corresponding decrease in OMC as the percentages of cement content increase with a constant $6 \%$ mango leaf waste ash for all the tests carried out for the sample. This was due to the agglomeration of large particles (sand and gravel) consuming bigger space with a comparable drop in dry density and in light of additional moisture needed for the hydration of cement and the pozzolanic response of mango leaf waste ash.
\end{abstract}

Keywords: Laterite, Mango leaf waste ash, Compaction characteristics, California Bearing Ratio (CBR), Unconfined Compressive Strength (UCS).

\section{Introduction}

Compaction is a conventional technique employed in civil engineering construction work and achieved by the application of mechanical energy to enhance the characteristics of the soil. This method densified the soil, rearranged the soil particles and removed the pore spaces [1]. The soil particles are close together in the compaction process, then caused the void ratio to be reduced, hence restricted the water movement in the soil particle and the process is widely used in the embankment construction like dam and roads [2]. However, the structures constructed with the tropical available soils,

Ishola K., Olawuyi O.A., and Kareem M.A.
(Department of Civil Engineering, Osun State
University, Osogbo)
Corresponding author's email address:
kazeem.ishola@ uniosun.edu.ng

especially lateritic soils have an advantage to the engineered earth fills.

Laterite is a typical soil that formed under the weathering systems that allow laterization process and is normally found in the drained soils of the moist tropics [1 \& 3]. The presence of iron and aluminum in the laterite has made its formation possible in hot and wet tropical areas. In addition, most lateritic soils have the characteristic of rusty red colouration due to the possession of high iron oxide content [1]. However, it is a dominant soil material that is used by engineers in Nigeria and other parts of the country for road pavements construction. The importance of lateritic soils for use as a construction material was due to the presence of cementing agents (sesquioxides) [4]. Many researchers have extensively investigated the Geotechnical characteristics of soils, especially those that found problematic with respect to 
earth dam and road pavement construction [4, 2,5].The common additives for soil improvement include cement, lime, bitumen and these added colours to the problematic soil which lead to the process known as stabilization. Soil improvement could be achieved by mechanical, chemical and biological means. However, the improvement in quality and hardness of lateritic soil in the present period has drawn researchers towards utilizing locally sourced material [6]. Sourcing for alternative soil as a replacement for problematic soil may demonstrate monetarily hasty, improve the soil by method for settling accessible soil to meet the ideal target turns into a practical choice $[1,7]$. Mango is a fruit type that is generally known, grows and harvested within the months of March - June annually.

Mango tree generates high quantities of leaves during the period that it is ready to produce new fruit, older leaves fell from the tree turn to waste which littered and polluted the environment of the grown area. The production quantities of these wastes have prompted researcher [8] to explore its use in soil development for the replacement of the conventional additives. Although, researchers have reported that it is widely used for medicinal purposes for curing diseases such as low blood pressure, stomach tonic and respiratory problems among others.

Awobifa [8] reported the percentage composition of mango leaf waste ash as $\mathrm{SiO}_{2}$ (43.79), $\mathrm{Al}_{2} \mathrm{O}_{3}(20.0)$ and $\mathrm{Fe}_{2} \mathrm{O}_{3}(1.01)$ is $64.8 \%$, which is over $50 \%$ required for class $\mathrm{C}$ pozzolanas but less than $70 \%$ required for class F and N-type pozzolanas by [9]. The researcher [10] categorized ash under the pozzolanas that range between $67-70 \%$ of silica, $4.9 \%$ (Alumina) and $0.95 \%$ (iron
oxide).The binding nature of the pozzolanic material causes a reduction in the permeability of embankments, strength increase in the soils and enhances the stability of embankments. The change in compaction characteristic of compacted soil is due to an alteration of soil gradation. The aim of this study is to investigate the effect of compaction on the lateritic soil- mango leaf ash admixed with cement using compactive efforts in terms of low (standard Proctor) and intermediate (West African standard) which falls between standard and modified Proctor energy levels.

\section{Materials and Methods}

\section{A. Laterite}

The laterite utilized for this work was gathered from the second gate area of Osun State University, Osogbo, Osun State, Nigeria. An investigation of the geographical and soil maps of Nigeria after [6] depicted the original material in the study area as a basic igneous rock which when weathered forms weakly developed lateritic soils.

\section{B. Mango leaf waste ash}

The mango leaf used was collected at the premises of Osun State University, Oke-baale, Osogbo, Osun State. The dried leaves at the base of the mango trees were obtained after which they were burnt under a controlled temperature of about $700^{\circ} \mathrm{C}-800^{\circ} \mathrm{C}$ to obtain the ashe. The ash was then passed through sieve No. 200 and the sieved fraction was used throughout the test. The sieved ash was corvered in a tight container to prevent moisture absorption. 


\section{Methods of Testing}

The laboratory tests conducted on the unmodified soil include particle size distribution, Atterberg limit, compaction, CBR and UCS. The properties of the soil were tested using [11] while the modified tests were carried in line with [12] procedures. Samples for unconfined compressive strength (UCS) and California Bearing Ratio (CBR) tests were established at the optimum moisture contents (OMC) and maximum dry densities (MDD). British Standard Light and West Africa Standard compactive efforts were utilized for soil-MLWA and cement blends. The tests especially CBR were guided as stated in the [13] and in this, samples that have been compacted were allowed to cure for six days prior to testing at a steady stacking rate. The MLWA was matched and sieved through BS sieve No $200(75 \mu \mathrm{m})$ before utilization. The mango leaf waste ash having $6 \%$ by dry weight of soil was mixed with the cement at an addition of 0,1 and $2 \%$ by dry weight of soil for every one of the blended samples.

\section{A. California Bearing Ratio}

The specimens in the $2360 \mathrm{~cm}^{3}$ compaction mould were placed in sealed plastic bags and cured for 6 days and thereafter immersed in water for 24 hours before testing in accordance with the provision of [13]. The California bearing ratio $(\mathrm{CBR})$ is expressed by the force exerted by the plunger and the depth of its penetration into the specimen; it is aimed at determining the relationship between force and penetration. From the values of the penetration and force recorded, a curve of force against penetration was obtained. The CBR value was calculated at the penetration of $2.5 \mathrm{~mm}$ or $5.0 \mathrm{~mm}$; the greater of the two values was taken as the CBR value for the soil - MLWA - cement mixtures

\section{B. Unconfined Compressive Strength}

Lateritic soil was treated with constant $6 \%$ MLWA, $1 \%, 2 \%$ cement content by dry weight of soil sample. Thoroughly mixed air-dried soil - MLWA - cement mixtures were compacted at optimum moisture contents (OMC) and compacted using standard Proctor (SP) energy. The compacted samples were extruded from the standard $1,000 \mathrm{~cm}^{3}$ mould using a cylindrical steel mould with a height of $76 \mathrm{~mm}$ and an internal diameter of $38 \mathrm{~mm}$. The specimens were sealed in polythene bags and kept in the humidity room at a constant temperature of $25 \pm 20 \mathrm{C}$ for 7 days curing period. The specimens were then placed in a load frame driven at a constant strain of 0.10 $\% /$ min until failure occurred.Three specimens were used for each test and the average result was taken.

\section{Test Results and Discussion}

\section{A. Soil Index Properties}

The soil was characterized by the following tests: (1) Particle size analysis; (2) specific gravity of soil solids; (3) liquid limit; (4) plastic limit; (5) plasticity index; (6) moisture-density relationships; (6) unconfined compressive strength; and (7) California bearing ratio. Figure 1 shows the Particle size distribution curve of natural soil. A synopsis of the soil properties (Table 1) and Physiochemical compositions of Lateritic soil, ordinary Portland cement, and Mango leaf waste was shown in Table 2. 
Table 1: Index properties of the natural soil

\begin{tabular}{ll}
\hline Properties & Quantity \\
\hline Natural Moisture Content $(\%)$ & 10.4 \\
Specific Gravity & 2.38 \\
Liquid Limit(\%) & 42.75 \\
Plastic Limit(\%) & 29.33 \\
Plasticity Index (\%) & 13.42 \\
Linear shrinkage (\%) & 7.1 \\
Percentage Passing BS No 4 & 93.3 \\
Sieve & \\
Percentage Passing BS No 200 & 54.4 \\
Sieve & \\
Maximum Dry Density $\left(\mathrm{Mg} / \mathrm{m}^{3}\right)$ & 1.52 \\
Optimum Moisture Content $(\%)$ & 21.7 \\
AASHTO Classification & A-7-6 (5) \\
\hline
\end{tabular}

Table 2: Physiochemical Composition of Lateritic soil, Cement and Mango leaf ash

\begin{tabular}{|c|c|c|c|}
\hline \multirow{2}{*}{$\begin{array}{l}\text { Oxide } \\
\text { Composition }\end{array}$} & \multicolumn{3}{|c|}{ Concentration (\%) } \\
\hline & $\begin{array}{l}\text { Lateritic } \\
\text { soil* }\end{array}$ & Cement** & $\begin{array}{l}\text { Mango } \\
\text { leaf*** }\end{array}$ \\
\hline $\mathrm{SiO}_{2}$ & 35.60 & 20.05 & 43.86 \\
\hline $\mathrm{Al}_{2} \mathrm{O}_{3}$ & 27.40 & 6.47 & 19.95 \\
\hline $\mathrm{Fe}_{2} \mathrm{O}_{3}$ & 24.0 & 2.79 & 1.03 \\
\hline $\mathrm{P}_{2} \mathrm{O}_{5}$ & & & \\
\hline $\mathrm{SO}_{3}$ & 0.85 & 0.35 & 0.12 \\
\hline $\mathrm{K}_{2} \mathrm{O}$ & & 0.51 & 30.55 \\
\hline $\mathrm{TiO}_{2}$ & & 0.38 & 0.01 \\
\hline $\mathrm{MnO}$ & 2.00 & & 0.02 \\
\hline $\mathrm{Na}_{2} \mathrm{O}$ & & 0.48 & 0.01 \\
\hline $\mathrm{CuO}$ & & & 0.03 \\
\hline $\mathrm{CaO}$ & 0.28 & 60.83 & 2.46 \\
\hline $\mathrm{ZnO}$ & 0.09 & & \\
\hline $\mathrm{MgO}$ & & 3.02 & \\
\hline $\begin{array}{l}\text { Loss of } \\
\text { Ignition }\end{array}$ & 14.6 & 1.51 & 15.25 \\
\hline
\end{tabular}

\section{B. Compaction Characteristics}

\section{(1) Maximum Dry Density}

Generally, MDD increased with a higher dosage of cement-MLWA to a peak value. The curve of the soil maximum dry densities and optimum moisture content of cement-MLA mixture are depicted in Figure 2 and Figure 3 respectively for BSL and WAS compactive efforts respectively. The MDD value increased from $2.40 \mathrm{Mg} / \mathrm{m}^{3}$ to $2.81 \mathrm{Mg} / \mathrm{m}^{3}$ with a higher percentage of cement. The variation of MDD for WAS also shows an increase up to $6 \%$ MLWA $/ 2 \%$ cement. A similar trend was reported by [15] where iron ore tailing was used to enhance the lateritic soil properties. The increase in MDD was due to cement / MLA occupies the space found in the soil moisture leading to the flocculation and agglomeration of the clay particles as a result of the ions exchange [16]. An analysis of variance (ANOVA) of the MDD BSL results show a significant effect of cement $\left(\mathrm{F}_{\mathrm{CAL}}=123.0233>\right.$ $\left.\mathrm{F}_{\mathrm{CRIT}}=18.51282\right)$ and MLA contents $\left(\mathrm{F}_{\mathrm{CAL}}=\right.$ $\left.105.8123>\mathrm{F}_{\text {CRIT }}=18.51282\right)$ on the lateritic soil while analysis of variance (ANOVA) for WAS results show a significant effect on cement $\left(\mathrm{F}_{\mathrm{CAL}}=134.558>\mathrm{F}_{\mathrm{CRIT}}=18.51282\right)$ and MLA contents $\left(\mathrm{F}_{\mathrm{CAL}}=51.8305>\mathrm{F}_{\mathrm{CRIT}}=\right.$ 19) on the lateritic soil.

\section{(2) Optimum Moisture Content}

The effects of cement on MLWA treated lateritic soil are shown in Fig. 2 and Fig. 3. Optimum moisture content (OMC) for British Standard Light (BSL) compactive effort decreased with a higher content of cement when $6 \%$ MLWA blended with up to $2 \%$ cement content. A Similar pattern was likewise revealed for WAS compactive effort as shown in Fig. 2 and Fig. 3. An analysis of variance (ANOVA) of the OMC for BSL results show a significant effect of Cement $\left(\mathrm{F}_{\mathrm{CAL}}=145.509\right.$ $\left.>\mathrm{F}_{\mathrm{CRIT}}=18.51282\right)$ and MLA contents $\left(\mathrm{F}_{\mathrm{CAL}}\right.$ $\left.=132.78>F_{\text {CRIT }}=19\right)$ on the lateritic soil with more significant effects on the mixture MLA treated soil. An analysis of variance (ANOVA) of the OMC WAS results show a significant effect of cement $\left(\mathrm{F}_{\mathrm{CAL}}=117.0537>\mathrm{F}_{\mathrm{CRIT}}=\right.$ 18.51282) and MLA contents $\left(\mathrm{F}_{\mathrm{CAL}}=151.576>\right.$ $F_{\text {CRIT }}=19$ ) on the lateritic soil with more significant effects on the more of MLWA of the treated soil.

\section{California Bearing Ratio}

The California bearing ratio (CBR) variation with cement/mango leaf waste ash content is depicted in Fig. 4. The unsoaked CBR for 


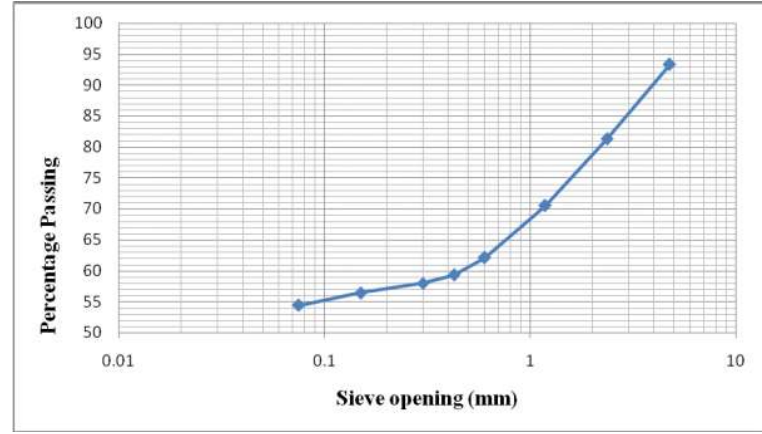

Figure 1. Particle size distribution curve of the natural soil

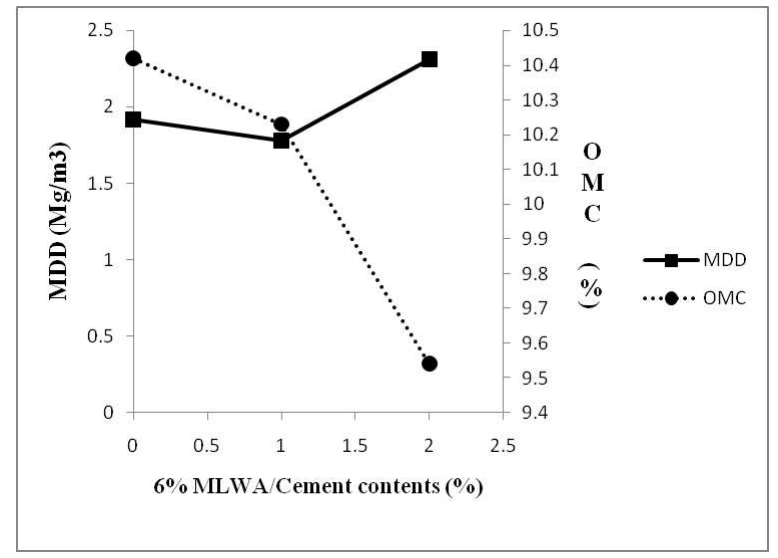

Figure 2. Variation of MDD and OMC of lateritic soil treated with cement and Mango leaf ash content (BSL)

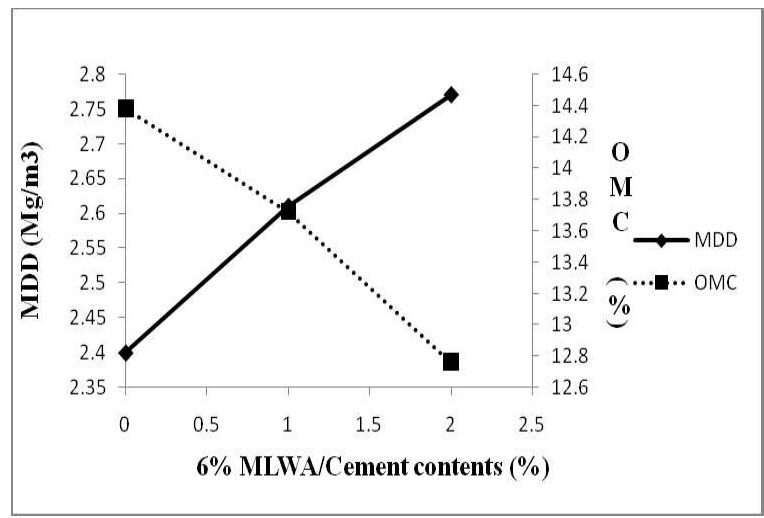

Figure 3. Variation of MDD and OMC of lateritic soil treated with cement and Mango leaf ash content (WAS) unmodified soil increased from $22.8 \%$ to the peak value of $23.4 \%$ with a higher $6 \%$ MLA /cement up to $2 \%$ of cement content. A similar trend in these findings was reported by [17]. The CBR values that are increasing with the more of cement-MLWA gave notice for the presence of enough calcium needed for the arrangement of calcium silicate hydrate (CSH) and calcium aluminate hydrate $(\mathrm{CAH})$ which are required compounds necessary for strength gain [18]. The value obtained for unsoaked CBR is not in line with the minimum CBR value of $30 \%$ specified by [13] for base material but improved for the sub-grade material requirement.

\section{Unconfined Compressive Strength}

Unconfined compressive strength (UCS) is a typical test that has been established for the evaluation of stabilized soil during construction. However, its use has brought about the required additive for soil stabilization [19]. The variation of the unconfined compression strength is shown in Fig 5 . Unconfined compressive strength of the treated lateritic soil compacted at BSL energy level increased from a natural value of $210 \mathrm{kN} / \mathrm{m}^{2}$ to the peak value of $214 \mathrm{kN} / \mathrm{m}^{2}$ when treated with constant $6 \%$ MLWA up to $2 \%$ cement. A similar trend was recorded for WAS where UCS increased up to $6 \%$ MLWA / 2\% cement/MLA given UCS value of 218 $\mathrm{kN} / \mathrm{m}^{2}$. The increasing trend of UCS value is in conformity with the works of [20] where cement kiln dust (CKD) was used to improve lateritic soil. The increase in UCS can be linked to a reduction in the amount of void present in the compacted soil-MLA mixture and hence giving more strength. An analysis of variance (ANOVA) of the UCS results show a significant effect of cement $\left(\mathrm{F}_{\mathrm{CAL}}=133.563>\right.$ 


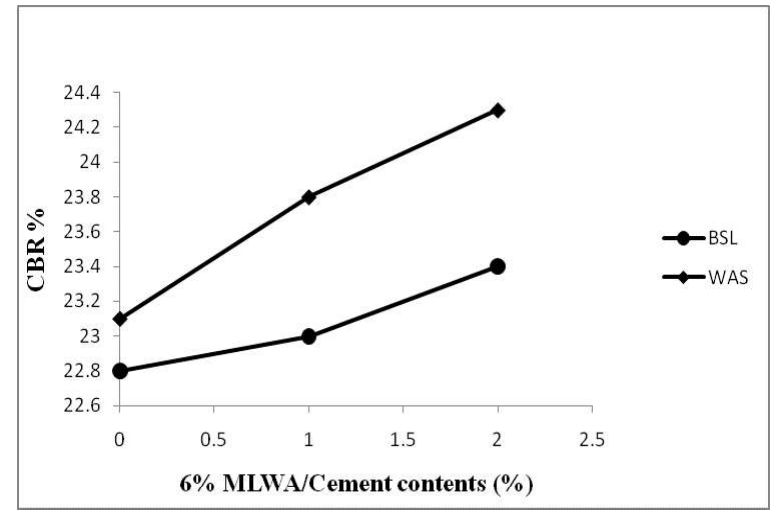

Figure 4. Variation of CBR of lateritic soil treated with cement and Mango leaf ash content

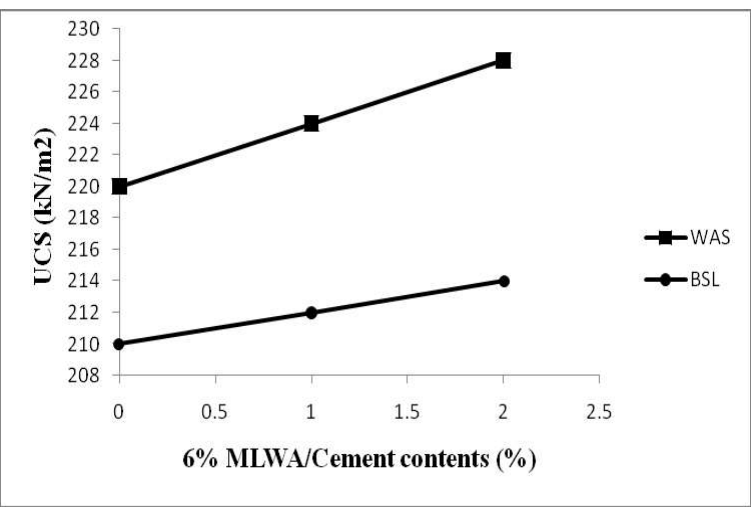

Figure 5. Variation of UCS of lateritic soil treated with cement and Mango leaf ash content

$\left.\mathrm{F}_{\text {CRIT }}=18.51282\right)$ and MLA contents $\left(\mathrm{F}_{\mathrm{CAL}}=\right.$ $\left.39>\mathrm{F}_{\mathrm{CRIT}}=19\right)$ on the lateritic soil with more significant effects with the increase of MLA on the treated soil.

\section{Conclusion}

Based on this study the following conclusions were drawn:

1. The lateritic soil used was classified as A-7-6 (5) and CL using AASHTO soil characterization and USCS respectively.

2. At a constant $6 \%$ MLWA dosage, a general decrease in MDD with a corresponding increase in $\mathrm{OMC}$ was observed for the addition of cement content up to $2 \%$.
3. The CBR and UCS of $6 \%$ MLWA-lateritic soil increased up to $2 \%$ cement content. This signifies improvements in the strength of the lateritic soil used, thus increasing the loadcarrying capacity of pavement.

\section{REFERENCES}

[1] Alhassan, M. and Mustapha, A.M "Review: Utilization of rice husk ash for improvement of deficient soils in Nigeria" Nigerian Journal of Technology Vol., 36, Number 2, 2017, pp $386-$ 394.

[2] Ellen, A. P. "Prediction of compaction characteristics of lateritic soils in Ghana" Unpublished M.Sc. Thesis, submitted to the Graduate school of applied sciences of near east university Nicosia. 2016

[3] Ishola, K., Olawuyi, O.A., Bello, A.A. and Yohanna, P. "Effect of Plantain Peel Ash on the Strength Properties of Tropical Red Soil Nigerian" Research Journal of Engineering and Environmental Sciences, Vol., 4, Number 1, 2019, pp 447-459

[4] AASHTO "Standard specifications for transportation materials and method of testing and sampling, American Association of State Highway and Transportation Officials", 1986, Washington D.C, USA.

[5] Oluremi. J.R., Yohanna. P., Ishola. K., Yisa. G.L., Eberemu. A. O., Ijimidiya. T.S.,Osinubi. K.J. Plasticity of Nigeria Lateritic Soil Admixed with Selected Admixtures, Journal of Environmental Geotechnics, Vol., 6, Number 3, 2017, pp.137-14

[6] Bello, A.A., Ige, J.A. and Ayodele, H. "Stabilization of Lateritic Soil with Cassava Peels Ash British, Journal of Applied Science and Technology, Vol., 7, Number 6, 2015 pp 642650.

[7] Osinubi, K. J. "Evaluation of Admixture Stabilization of Nigerian Black Cotton Soil". Nigeria Society of Engineers Technical Transaction, Vol.34, Number 33, 1999, pp 8896. 
[8] Awobifa, "Geotechnical Properties of Lateritic Soil Stabilized with Mango Leaf Waste Ash Unpublished, B. Eng. Project, Department of Civil Engineering, Osun State University, Osogbo, 2018.

[9] ASTM C618-78. "Specification for Fly Ash and Raw Calcined Natural Pozzolana for use as a

Mineral Admixture in Portland Cement Concrete".American Society for Testing and Materials, Philadelphia. 1978.

[10] Oyetola, E. B., and Abdullahi M. (2006) The Use of Rice Husk Ash in Low-Cost Sandcrete Block Production, Leonardo Electronic Journal of Practice and Technologies, Vol.8. 2006 pp 58-70.

[11] B. S. 1377 "Methods of testing soil for civil engineering purposes, British standards institute London, 1990.

[12] B. S. 1924 "Methods of testing for stabilized soils, British standards institute", London. 1990

[13] Nigerian General Specifications (1997). Roads and Bridges. Federal Ministry of Works, Abuja, Nigeria, 1997.

[14] Emeka, S.E and Aderinlewo.O.O "Geotechnical Properties of Lateritic Soil Stabilized with Banana Leaves Ash" FUOYE Journal of Engineering and Technology, Vol. 1, Number 1, 2016, pp 116-119.

[15] Ishola, K. Modification of Laterite Soil with Iron Ore Tailing. Unpublished M.Sc. thesis, Civil Engineering Department, Ahmadu Bello University, Zaria. 2014.

[16] Salahudeen, A. B., Eberemu, A. O., Osinubi, K. J. Assessment of Cement Kiln DustTreated Expansive Soil for the Construction of Flexible Pavements Geotechnical and Geological Engineering, 2014, pp. 1-11

[17] Salahudeen, A.B. and Ochepo J. "Effect of Bagasse Ash on Some Engineering Properties of Lateritic Soil", Jordan Journal of Civil Engineering, Vol., 9, Number 4, 2015, pp 468476.

[18] Salahudeen, A.B., and Akiije, I."Stabilization of highway expansive soils with a high loss on ignition content kiln dust". Nigerian Journal of
Technology (NIJOTECH), Vol., 33, Number 2, 2014, pp 141-148.

[19] Alhassan, M and Alhaji, M. M. "Utilisation of Rice Husk Ash for Improvement of Deficient Soils in Nigeria: A Review" Nigerian Journal of Technology Vol. 36, Number. 2, 2017, pp. $386-394$

[20] Oluremi, J.R., Siddique, R., and Adeboje, E.P. "Stabilization Potential of Cement Kiln Dust Treated Lateritic Soil" International Journal of Engineering Research in Africa, Vol. 23, 2016, pp 52-63. 